\title{
Cyclic Voltammetric studies of Calcium acetate salt with Methylene blue Using Gold Electrode
}

\author{
Mohamed. M. El-Defrawy, Esam. A.Gomaa (D), Shereen. E. Salem, Fatma.M. Abdel Razek
}

Chemistry Department, Faculty of Science, Mansoura University, 35516-Mansoura, Egypt

H I G H L I G H T S

- Detecting of calcium ions in form of acetate by cyclic voltammetry.

- Good detection of calcium ions at suitable potentials and not large potentials as usual.

- Complexation study with methylene blue which help in analytic determination of calcium ions.

- Determining the thermodynamic parameters for interaction of calcium ions with methylene blue.

$\overline{\text { ART I C LE INFO }}$

Article history:

Received: 2018-0ct-25

Accepted: 2018-Nov-18

Available online: 2018-Nov-25

Manuscript ID: PCBR-1810-1001

Keywords

Cyclic Voltammetry

Gold Electrode

Calcium acetate

Methylene blue

Redox reaction

Solvation parameters
GRAPHICAL ABSTRACT

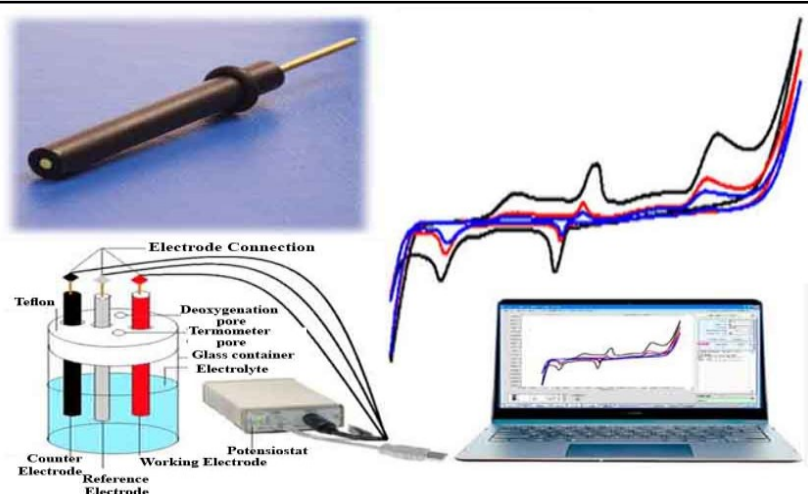

A B S T R A C T

Cyclic Voltammetric studies of calcium acetate salt $\left[\mathrm{Ca}\left(\mathrm{CH}_{3} \mathrm{COO}\right)_{2}\right]$ in absence or presence of Methylene blue (MB) were performed to predict and analyze the behavior of complexation between the ligand and metal ion in aqueous solution. From these studies, the values of solvation and kinetic parameters $\left[\mathrm{E}_{\mathrm{p}}\right.$ (peak potential), Ip (peak current), $\Delta \mathrm{E}_{\mathrm{P}}$ (peak potential difference), $E_{1 / 2}$ (half wave potential), $D$ (Diffusion coefficient), $K_{S}$ (electron transfer rate constant), $\Gamma$ (surface coverage) and $Q_{a}$ (quantity of electricity)] were evaluated. In addition, the effect of different concentration and a scan rate of above the calculated quantities were studied. In case of presence MB, the stability constants and Gibbs free energies were performed.

\section{Introduction}

Calcium acetate is used to decrease and prevent blood phosphate levels in patients suffering from dialysis due to kidney disease [1]. Hyperphosphatemia has a universal effect in patients with chronic disease [2]. Dialysis can remove some phosphate from the blood, but it is hard to remove enough to control the phosphate level[1, 2]. Decreasing on the blood phosphate levels help to keep bones strong, prevent unsafe build up of minerals in the body and decrease the heart diseases. Calcium acetate is a natural mineral that works by extracting phosphate from the diet so that it passes out of the body[1].

Theoretical calculations, using equilibrium constants should be an effective phosphate binder[3]. In vitro experiments confirmed the theoretical binder[3]. In vivo 
studies in normal subjects found calcium acetate to be more phosphorous binding than calcium carbonate[4].

Analytical determination of calcium acetate is therefore important to follow them in foods, environment and human bodies, which is our main target. Using cyclic voltammetry as electroanalytical tool for evaluation of calcium acetate is very important. Gold working electrode (GE) was prepared in our laboratory, facilitating the easy determination of calcium acetate in aqueous solutions. Calcium ions are well detected here using GE in opposite to that by using glassy carbon electrode which will appear at a high voltage area.

\section{Experimental}

\subsection{Reagents and solutions}

The chemicals used are calcium acetate salt [Ca $\left.\left(\mathrm{CH}_{3} \mathrm{COO}\right)_{2}\right], \mathrm{HCl}$ and methylene blue from Sigma Aldrich Company (purity 98\%). Pure water was used by distillation.

\subsection{Instrumentation}

The cyclic voltammetric studies were done by using a potentiostat of the type DY2000, delivered from USA. It was connected to a cell of three electrodes, $\mathrm{Ag} / \mathrm{AgCl}, \mathrm{KCl}_{\text {sat }}$ was used as reference electrode, gold electrode (GE) was used as working electrode and platinum wire, auxiliary electrode. GE was prepared in our laboratory from pure gold wire $18 \mathrm{~K}$ bought from famous jewelling shop jointed with steel rod, isolated, covered with heat shrink polymer and polished good by woollen piece before using. Area of electrode is $7.853 \times 10^{-3} \mathrm{~cm}^{2}$. The system was applied from 1.6 to $-1.6 \mathrm{~V}$ potential windows and $0.1,0.02,0.01 \mathrm{v} / \mathrm{s}$ as scan rates at constant temperature $294.85 \mathrm{~K}$. Flow of purified $\mathrm{N}_{2}$ was done to ensure removal of $\mathrm{O}_{2}$ and diffusion experiment.

\section{Results and Discussion}

3.1. Electrochemical behavior of $\mathrm{Ca}^{+2}$ ions in absence of ligand, $\mathrm{MB}$ at $294.85 \mathrm{~K}$.

3.1.1. Solvation and kinetic parameters in absence of $M B$.

First, the cyclic voltammogram of $30 \mathrm{ml} \mathrm{HCl}(0.1 \mathrm{M})$ as a supporting electrolyte was measured from 1.6 to $-1.6 \mathrm{~V}$ of potential window, the current is measured in Ampere unit, whereas the scan is $0.1 \mathrm{~V} / \mathrm{S}$ (volt per second) at
294.85 K, (Fig.1). Then, the redox behavior of $\mathrm{Ca}^{+2}$ ions was examined in $0.1 \mathrm{M}$ of $\mathrm{HCl}$ at $294.85 \mathrm{~K}$. The $\mathrm{Ca}^{+2}$ ions solution is added step wisely from $0.2 \mathrm{ml}\left(6.62 \times 10^{-4} \mathrm{M}\right)$ to reach until $1 \mathrm{ml}\left(3.23 \times 10^{-3} \mathrm{M}\right)$ as shown in (Fig.2).

The electrochemical redox behavior of $\mathrm{Ca}^{+2}$ ions in absence of MB at the GE was studied at the steady state current, cyclic waves were obtained and explained using the following equation (1) [5-8]:

$$
\mathrm{i}_{\mathrm{p}}=0.4463 \text { n F A C }(\mathrm{n} \mathrm{F} \mathrm{D} / \mathrm{R} \mathrm{T})^{1 / 2}
$$

$i_{p}$ is the current in Ampere, $A$ is the surface area of working electrode in $\mathrm{cm}^{2}, \mathrm{D}$ is the diffusion coefficient in $\mathrm{cm}^{2} / \mathrm{Sec}, v$ is the scan rate in volts/Sec and $\mathrm{C}$ is the concentration of the $\mathrm{Ca}^{+2}$ ions.

The peak potential difference, $\Delta \mathrm{E}_{\mathrm{P}}$ is calculated from equation (2):

$$
\Delta \mathrm{E}_{\mathrm{P}}=\mathrm{E}_{\mathrm{Pa}}-\mathrm{E}_{\mathrm{Pc}}
$$

If $\Delta \mathrm{E}_{\mathrm{P}}$ will close to $59 / \mathrm{n} \mathrm{mv}$ (at $25^{\circ} \mathrm{C}$ ) the reaction is reversible where, $\mathrm{n}$ is the number of electrons in redox reactions.

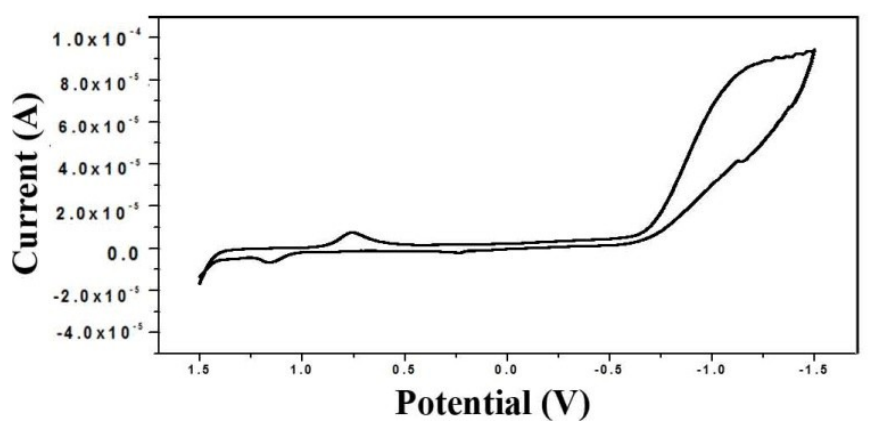

Fig.1. Cyclic voltammogram of $30 \mathrm{ml} \mathrm{HCl}(0.1 \mathrm{M})$ as a supporting electrolyte at $294.85 \mathrm{~K}$ and scan rate $0.1 \mathrm{~V} / \mathrm{S}$.

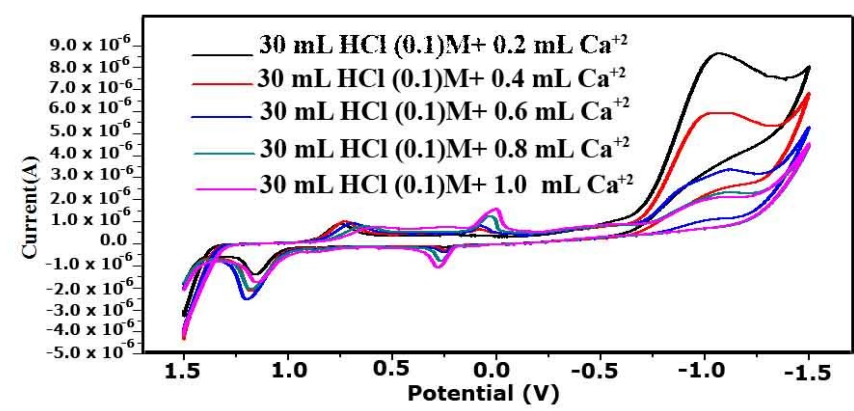

Fig.2. Cyclic voltammogram of different $\mathrm{Ca}^{+2}$ ions concentrations in 30 $\mathrm{ml} \mathrm{HCl}(0.1 \mathrm{M})$ and scan rate $0.1 \mathrm{~V} / \mathrm{S}$ at $294.85 \mathrm{~K}$. 
The standard heterogeneous electron transfer rate constant $\mathrm{k}_{\mathrm{s}}$ in $\mathrm{cm} / \mathrm{sec}$ was calculated by applying the following equation $(3)[9,10]$ :

$$
\mathrm{k}_{\mathrm{s}}=2.18^{*}\left[\mathrm{D}_{\mathrm{C}} \alpha \mathrm{n}_{\mathrm{a}} \mathrm{F} v / \mathrm{RT}\right]^{1 / 2} * \exp \left[\alpha^{2} \mathrm{nF} \Delta \mathrm{E}_{\mathrm{P}} / \mathrm{RT}\right]
$$

Where, $\alpha$ is charge transfer coefficient and $n_{a}$ is the numbers of electron transfer in the rate determining step. Assuming that $\alpha$ coefficient is equal to 0.5 . Hence, $\alpha \mathrm{n}_{\mathrm{a}}$ will be as the shown in equation (4):

$$
\alpha \mathrm{n}_{\mathrm{a}}=1.857 \mathrm{RT} /\left(\mathrm{E}_{\mathrm{pc}}-\mathrm{E}_{\mathrm{pc} / 2}\right) \mathrm{F}
$$

Where $E_{p c / 2}$ is the half wave potential for cathodic peak. Then the surface coverage $\Gamma$ (surface concentration of the electroactive species in mol.cm-2) was evaluated by equation $(5)[11,12]$ :

$$
\Gamma=\mathrm{i}_{\mathrm{p}} 4 \mathrm{RT} / \mathrm{n}^{2} \mathrm{~F}^{2} \mathrm{Av}
$$

The quantity of charge consumed during the reduction or adsorption of the adsorbed layer can be used to calculate the surface coverage by eq. (6)[13]:

$$
\mathrm{Q}=\mathrm{n} F A \Gamma
$$

The different cyclic Voltammetry analysis data were calculated and the obtained data are $\mathrm{Ep}_{\mathrm{a}}$ (anodic peak potential), $\mathrm{Ep}_{\mathrm{c}}$ (cathodic peak potential), Ip $\mathrm{p}_{\mathrm{a}}$ (anodic peak current), $\mathrm{Ip}_{\mathrm{c}}$ (cathodic peak current), $\Delta \mathrm{E}_{\mathrm{P}}$ (peak potential difference), $E_{1 / 2}$ (half wave potential), $D_{a}$ (anodic diffusion coefficient), $\mathrm{D}_{\mathrm{c}}$ (cathodic diffusion coefficient), $\mathrm{K}_{\mathrm{s}}$ (electron transfer rate constant), $\Gamma_{\mathrm{a}}$ (anodic surface coverage), $\Gamma_{\mathrm{c}}$ (cathodic surface coverage), $Q_{a}$ (anodic quantity of electricity) and $Q_{c}$ (cathodic quantity of electricity) in Table 1.(a,b)[14-18].

Fig. 3 illustrates the relation between cathodic and anodic peak current Ip against different concentrations of $\mathrm{Ca}^{+2}$ ions in $0.1 \mathrm{M} \mathrm{HCl}$ gives straight lines indicating the reversibility of the mechanisms.

All the kinetic parameters $\left[D_{a}, D_{c}, K_{s}, Q_{a}, Q_{c}, \Gamma_{a}, \Gamma_{c}\right]$ for $\mathrm{Ca}^{+2}$ ions concentration are increased by increasing in the concentrations of calcium acetate favoring diffusion controlled reactions. Fig. 3 gave a straight line relationship between current (i) and $\mathrm{Ca}^{+2}$ ion concentrations for both cathodic and anodic peaks supporting also the diffusion reaction.

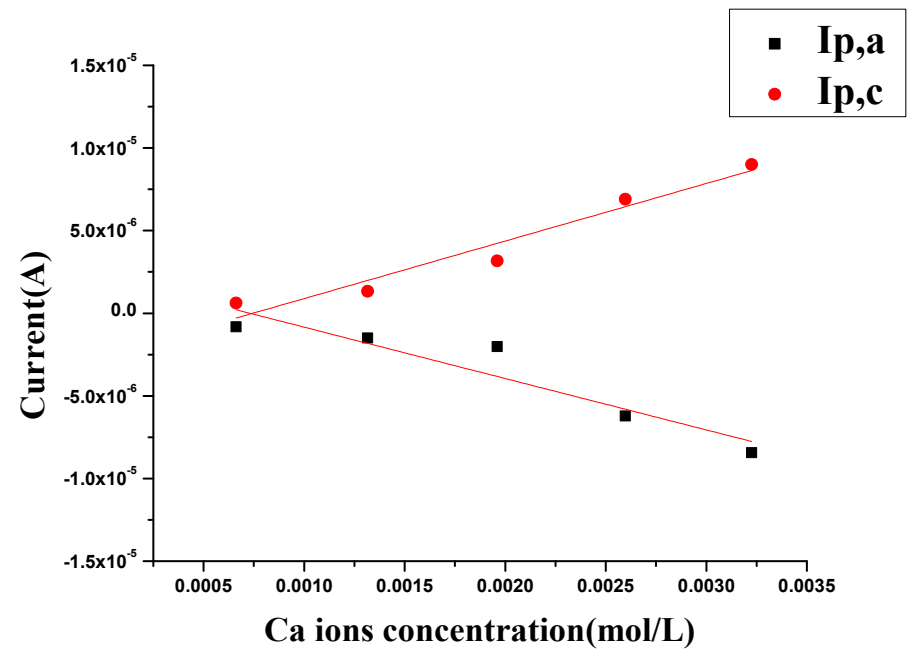

Fig.3. The relation between peak current Ip (ip,a - ip,c) against different concentrations of $\mathrm{Ca}^{+2}$ ions at $294.85 \mathrm{~K}$ and scan rate 0.1 $\mathrm{V} / \mathrm{S}$.

\subsubsection{Effect of different scan rates}

Effect of different scan rates for the redox behavior of $\mathrm{Ca}^{+2}$ ions in $0.1 \mathrm{M} \mathrm{HCl}$ was studied in the range $0.1,0.02$ and $0.01\left(\right.$ V.s $^{-1}$ ) at $294.85 \mathrm{~K}$, (Fig.4). The solvation and kinetic parameters (Ep, Ip, $\Delta \mathrm{E}_{\mathrm{P}}, \mathrm{E}_{1 / 2}, \mathrm{D}, \mathrm{k}_{\mathrm{S}}, \Gamma$ and $\mathrm{Q}$ ) of different scan rates of $\mathrm{Ca}^{+2}$ ions were presented in Table. 2 (a,b).

Randless Sevicek equation (10-17) was used to apply the relation between cathodic and anodic peak current Ip against the square root of scan rate in $0.1 \mathrm{M} \mathrm{HCl}$ which gives straight lines indicating diffusion process as shown in Fig.5.

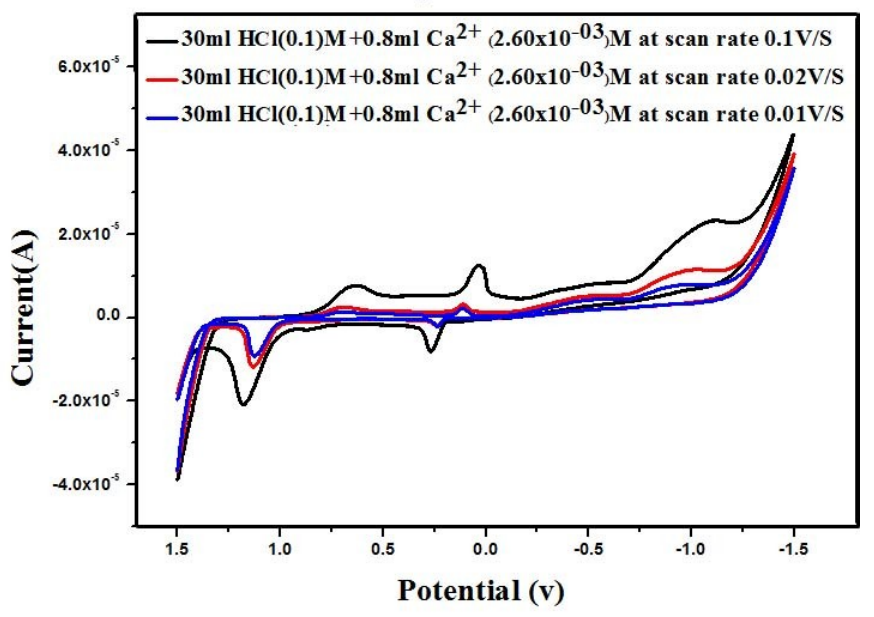

Fig.4. Cyclic voltammogram of different scan rates of $2.60 \times 10^{-03} \mathrm{M}$ $\mathrm{Ca}^{+2}$ ions in $0.1 \mathrm{M} \mathrm{HCl}$ at $294.85 \mathrm{~K}$. 
Table.1 (a): The solvation and kinetic parameters $\left[\mathrm{Ep}_{\mathrm{a}}, \mathrm{Ep}_{\mathrm{c}}, \mathrm{Ip}_{\mathrm{a}}, \mathrm{Ip}_{\mathrm{c}}, \Delta \mathrm{E}_{\mathrm{p}}, \mathrm{E}_{1 / 2}\right]$ of different concentrations of $\mathrm{Ca}^{+2}$ ions at scan rate $0.1 \mathrm{~V} / \mathrm{S}$ and $294.85 \mathrm{~K}$.

\begin{tabular}{|c|c|c|c|c|c|c|c|}
\hline $\mathrm{mL}$ of $\mathrm{M}$ & $\begin{array}{c}{[\mathrm{M}]} \\
\left(\mathrm{mol} . \mathrm{L}^{-1}\right)\end{array}$ & $\begin{array}{c}\mathrm{Ep}_{\mathrm{a}} \\
(\mathrm{V})\end{array}$ & $\begin{array}{c}\mathrm{Ep}_{\mathrm{c}} \\
(\mathrm{V})\end{array}$ & $\begin{array}{c}(-) \mathrm{I}_{\mathrm{a}} \times 10^{-6} \\
(\mathrm{~A})\end{array}$ & $\begin{array}{c}\mathrm{Ip}_{\mathrm{c}} \times 10^{-6} \\
(\mathrm{~A})\end{array}$ & $\Delta \mathrm{E}_{\mathrm{p}}(\mathrm{V})$ & $\mathrm{E}_{1 / 2}(\mathrm{~V})$ \\
\hline 0.2 & 0.0006 & 0.246 & 0.105 & 0.824 & 0.618 & 0.142 & 0.175 \\
\hline 0.4 & 0.0013 & 0.243 & 0.086 & 1.50 & 1.33 & 0.157 & 0.164 \\
\hline 0.6 & 0.0019 & 0.245 & 0.079 & 2.02 & 3.17 & 0.166 & 0.162 \\
\hline 0.8 & 0.0025 & 0.264 & 0.036 & 6.23 & 6.92 & 0.228 & 0.150 \\
\hline 1 & 0.0032 & 0.278 & 0.006 & 8.44 & 9.00 & 0.272 & 0.142 \\
\hline
\end{tabular}

Table.1 (b): The solvation and kinetic parameters $\left[\mathrm{D}_{\mathrm{a}}, \mathrm{D}_{\mathrm{c}}, \mathrm{K}_{\mathrm{s}}, \Gamma_{\mathrm{a}}, \Gamma_{\mathrm{c}}, \mathrm{Qa}, \mathrm{Qc}\right]$ of different concentrations of $\mathrm{Ca}^{+2}$ ions at scan rate $0.1 \mathrm{~V} / \mathrm{S}$ and $294.85 \mathrm{~K}$.

\begin{tabular}{|c|c|c|c|c|c|c|c|c|}
\hline $\mathrm{mL}$ of M & $\begin{array}{c}{[\mathrm{M}]} \\
\left(\mathrm{mol}^{-1}\right)\end{array}$ & $\begin{array}{c}\text { Dax10-12 } \\
\left(\mathrm{cm}^{2} . \mathrm{s}^{-1}\right)\end{array}$ & $\begin{array}{c}\mathrm{Dcx} 10^{-12} \\
\left(\mathrm{~cm}^{2} . \mathrm{s}^{-1}\right)\end{array}$ & $\begin{array}{c}\mathrm{K}_{\mathrm{s}} \mathrm{C} \times 10^{-4} \\
\left(\mathrm{~cm} \cdot \mathrm{s}^{-1}\right)\end{array}$ & $\begin{array}{c}\Gamma \mathrm{c} \times 10^{-9} \\
\left(\mathrm{~mol} / \mathrm{cm}^{2}\right)\end{array}$ & $\begin{array}{c}(+) \mathrm{Qc} \times 10^{-6} \\
(\mathrm{C})\end{array}$ & $\begin{array}{c}\Gamma \mathrm{a} \times 10^{-9} \\
\left(\mathrm{~mol} / \mathrm{cm}^{2}\right)\end{array}$ & $\begin{array}{c}(-) \mathrm{Qa} \\
\mathrm{x} 10^{-6} \\
(\mathrm{C})\end{array}$ \\
\hline 0.2 & 0.0006 & 0.430 & 0.242 & 0.421 & 0.207 & 0.314 & 0.276 & 0.419 \\
\hline 0.4 & 0.0013 & 0.360 & 0.284 & 0.629 & 0.446 & 0.676 & 0.502 & 0.761 \\
\hline 0.6 & 0.0019 & 0.294 & 0.726 & 1.25 & 1.062 & 1.61 & 0.676 & 1.02 \\
\hline 0.8 & 0.0025 & 1.60 & 1.97 & 5.50 & 2.321 & 3.52 & 2.089 & 3.16 \\
\hline 1 & 0.0032 & 1.90 & 2.17 & 11.2 & 3.020 & 4.58 & 2.831 & 4.29 \\
\hline
\end{tabular}

Table.2(a): The solvation and kinetic parameters $\left(\mathrm{Ep}_{\mathrm{a}}, \mathrm{Ep}_{\mathrm{c}}, \mathrm{Ip}_{\mathrm{a}}, \mathrm{Ip}_{\mathrm{c}}, \Delta \mathrm{E}_{\mathrm{p}}, \mathrm{E}_{\mathrm{1} / 2}\right)$ of different scan rates of 2.60x10-03 $\mathrm{M} \mathrm{Ca}^{+2}$ ions at $294.85 \mathrm{~K}$.

\begin{tabular}{|c|c|c|c|c|c|c|}
\hline$v$ & $\begin{array}{c}E p_{a} \\
(v)\end{array}$ & $\begin{array}{c}E p_{c} \\
(v)\end{array}$ & $(-) I p, a(A) \times 10^{-6}$ & Ip,c(A) x10-6 & $\begin{array}{c}\Delta E_{p} \\
(v)\end{array}$ & $\begin{array}{c}E_{1 / 2} \\
(v)\end{array}$ \\
\hline 0.1 & 0.264 & 0.0361 & 6.23 & 6.92 & 0.228 & 0.150 \\
\hline 0.02 & 0.232 & 0.112 & 1.35 & 1.49 & 0.121 & 0.172 \\
\hline 0.01 & 0.231 & 0.114 & 1.61 & 1.61 & 0.116 & 0.173 \\
\hline
\end{tabular}

Table.2(a): The solvation and kinetic parameters $\left(D_{a}, D_{c}, K_{s}, \Gamma_{a}, \Gamma_{c}, Q a, Q c\right)$ of different scan rates of $2.60 \times 10^{-03} \mathrm{M} \mathrm{Ca}^{+2}$ ions at $294.85 \mathrm{~K}$.

\begin{tabular}{|c|c|c|c|c|c|c|c|}
\hline $\mathrm{u}$ & $\begin{array}{c}\mathrm{Da} \times 10^{-12} \\
\left(\mathrm{~cm}^{2} \cdot \mathrm{s}^{-1}\right)\end{array}$ & $\begin{array}{c}\mathrm{Dc} \times 10^{-12} \\
\left(\mathrm{~cm}^{2} \mathrm{~s}^{-1}\right)\end{array}$ & $\begin{array}{c}\mathrm{K}_{\mathrm{s}} \mathrm{C} \times 10^{-5} \\
\left(\mathrm{~cm} \cdot \mathrm{s}^{-1}\right)\end{array}$ & $\begin{array}{c}\Gamma \mathrm{c} \times 10^{-9} \\
\left(\mathrm{~mol} / \mathrm{cm}^{2}\right)\end{array}$ & $\begin{array}{c}++) \mathrm{Qc} \\
\mathrm{x} 10^{-6}(\mathrm{C})\end{array}$ & $\Gamma \mathrm{a} \times 10^{-9}\left(\mathrm{~mol} / \mathrm{cm}^{2}\right)$ & $\begin{array}{c}(-) \mathrm{Q} a \\
\mathrm{x} 10^{-6}(\mathrm{C})\end{array}$ \\
\hline 0.1 & 1.60 & 1.97 & 0.550 & 2.32145 & 3.52 & 2.0893 & 3.16 \\
\hline 0.02 & 0.377 & 0.457 & 2.06 & 2.49759 & 3.78 & 2.2705 & 3.44 \\
\hline 0.01 & 1.06 & 1.06 & 1.97 & 5.38974 & 8.16 & 5.3897 & 8.16 \\
\hline
\end{tabular}

The diffusion mechanism is also supported by scan rate effect which shows an increase in height of the waves by increasing scan rate.

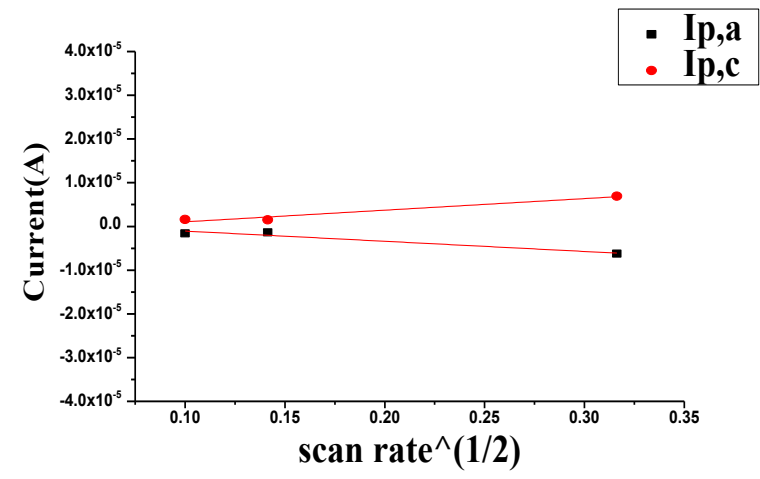

Fig.5. The relation between peak current Ip (ip,a - ip,c) against the square root of different scan rates for $\mathrm{Ca}^{+2}$ ions at $294.85 \mathrm{~K}$.
3.2. Electrochemical behavior of $\mathrm{Ca}^{+2}$ ions in presence of ligand, $M B$ at $294.85 \mathrm{~K}$.

\subsubsection{Effect of different MB concentrations.}

\subsubsection{Solvation and kinetic parameters in presence of $M B$.}

The electrochemical behavior of the complexation between $\mathrm{MB}$ and $\mathrm{Ca}^{+2}$ ions in $0.1 \mathrm{M} \mathrm{HCl}$ at $294.85 \mathrm{~K}$ with $1.6 \mathrm{~V}$ to $-1.6 \mathrm{~V}$ potential windows and scan rate $0.1 \mathrm{~V} / \mathrm{S}$ were shown in Fig. 6.

The electrochemical redox behavior of $\mathrm{Ca}^{+2}$ ions in the presence of MB at the GE was studied at the steady state current, cyclic waves were obtained and explained using equations (1-6). 


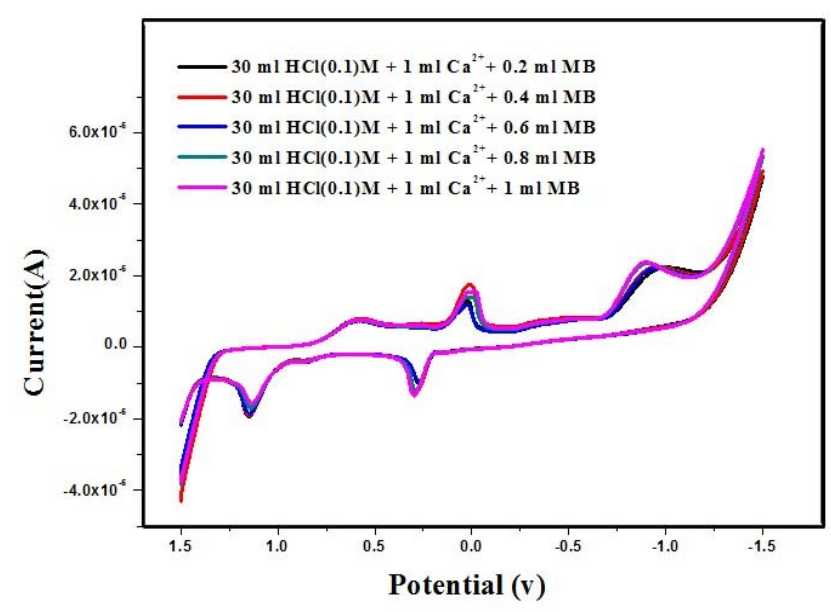

Fig.6. Cyclic voltammograms for the interaction of $3.2 \times 10^{-3} \mathrm{M} \mathrm{Ca}^{+2}$ ions and different concentrations of $\mathrm{MB}$ at $294.85 \mathrm{~K}$ and scan rate $0.1 \mathrm{~V} / \mathrm{S}$.

The solvation and kinetic parameters (Ep, Ip, $\Delta \mathrm{E}_{\mathrm{P}}, \mathrm{E}_{1 / 2}, \mathrm{D}, \mathrm{k}_{\mathrm{S}}$, $\Gamma$ and Q) of interaction of $3.2 \times 10^{-3} \mathrm{M} \mathrm{Ca}^{+2}$ ions and different concentrations of Methylene blue at $294.85 \mathrm{~K}$ and scan rate $0.1 \mathrm{~V} / \mathrm{S}$ were presented in Table 3.(a,b).

Randless Sevicek equation (6-10) was used to apply the relation between cathodic and anodic peak current Ip against different concentrations of $\mathrm{Ca}$ ions in the presence of $\mathrm{MB}$ which gives straight lines indicating diffusion process as shown in Fig.7.

The gold wave at -1.0 volt is slightly affected by calcium acetate in the presence of MB due to the complexation reaction between metal ions $\left(\mathrm{Ca}^{2+}\right)$ and MB.

The calcium peaks illustrated before at 0.0 and $0.25 \mathrm{~V}$ are increasing in intensity, height by more adding MB to Ca ions, shifted to more negative values for the reduction peak and more positive values for the oxidation wave. All the results indicate complexation reaction between $\mathrm{MB}$ and $\mathrm{Ca}$ ions as calcium acetate.

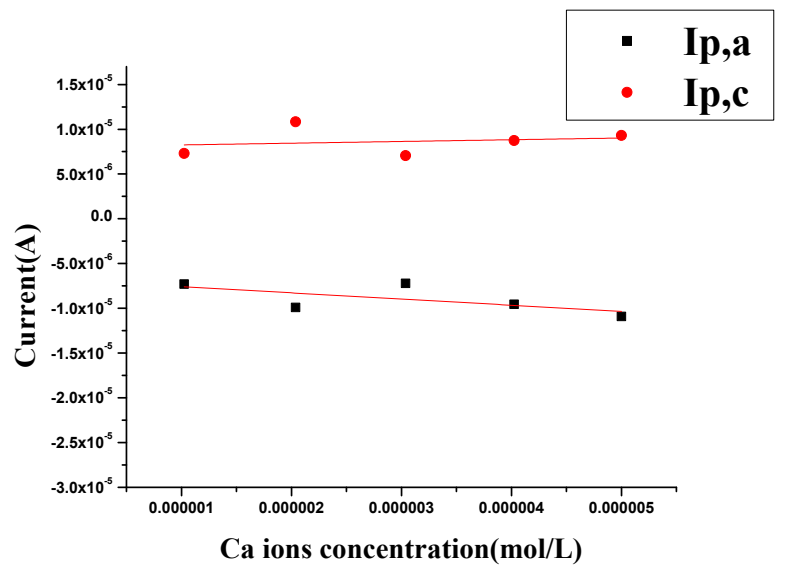

Fig.7. The relation between peak current Ip (ip,a - ip,c) against $\mathrm{Ca}^{+2}$ ions concentrations in the presence of $\mathrm{MB}$ at $294.85 \mathrm{~K}$ and scan rate $0.1 \mathrm{~V} / \mathrm{S}$.
The kinetic parameters $\left[D_{a}, D_{c}, K_{s}, Q_{a}, Q_{c}, \Gamma_{a}, \Gamma_{c}\right]$ for the interaction of $\mathrm{MB}$ with calcium acetate are smaller than that of calcium acetate solutions alone indicating complexation reaction between Ca ions and MB ligand.

\subsubsection{Electrochemical behavior of the complexation between $M B$ and Ca ions.}

From Fig.6, it is observed that the complex is formed as a result of decreasing in the anodic and cathodic peak beside the potential shifts to new values. Due to precipitating the complex during the process, no peak appeared. A stability constant is a measure of the strength of the interaction between the reagents that come together to form the complex. The stability constants $\left(\beta_{\mathrm{Mx}}\right)$ for bulk and nano cadmium chloride complexes for each addition are calculated by applying Eq. $(10)[5,16]$ :

$\Delta \mathrm{E}^{\circ}=\mathrm{E}_{\mathrm{C}}{ }^{\mathrm{C}}-\mathrm{E}_{\mathrm{M}}^{\mathrm{o}}=2.303(\mathrm{RT} / \mathrm{nF}) *\left(\log \beta_{\mathrm{MX}}+\mathrm{j} \log \mathrm{C}_{\mathrm{X}}\right)$

Where $\mathrm{E}_{\mathrm{M}}^{\circ}$ is the formal peak potential of metal at finally adding in the absence of ligand, $\mathrm{E}_{\mathrm{C}}^{\circ}$ is the formal peak potential of metal complex after each addition of $\mathrm{MB}, \mathrm{R}$ is a gas constant $\left(8.314 \mathrm{~J} \cdot \mathrm{mol}^{-1}\right.$.degree $\left.{ }^{-1}\right), \mathrm{T}$ is the absolute temperature, $\mathrm{j}$ is the coordination number of the Stoichiometric complex and $C_{x}$ is the concentration of MB in the solution.

The formal potential $\mathrm{E}^{\circ}$ can be found as the midway between the two cyclic voltammetric peaks comprising the voltammogram by equation (11):

$$
E^{\circ}=\left(E_{p a}+E_{p c}\right) / 2
$$

Where both $E_{p a}$ and $E_{p c}$ are anodic peak potential and cathodic peak potential, respectively

The Gibbs free energy of interaction for $\mathrm{Ca}^{+2}$ ions with $\mathrm{MB}$ were calculated from stability constant $\left(\beta_{\mathrm{MX}}\right)$ using Eq. (12) [10-20]:

$$
\Delta \mathrm{G}=-2.303 \mathrm{RT} \log \beta_{\mathrm{MX}}
$$

The calculated values of $\mathrm{E}^{\circ}, \beta_{\mathrm{Mx}}$ and $\Delta \mathrm{G}$ for $\mathrm{Ca}^{+2}$ ion complexes are estimated and collected in Table 4.

The thermodynamic parameters $\beta \mathrm{j}$ and $\Delta \mathrm{G}$ for the interaction of MB with calcium acetate are increased by increasing the concentration of MB in solutions indicating more complexation. 
Table3.(a): The solvation and kinetic parameters $\left(\mathrm{Ep}_{\mathrm{a}}, \mathrm{Ep}_{\mathrm{c}}, \mathrm{Ip}_{\mathrm{a}}, \mathrm{Ip}_{\mathrm{c}}, \Delta \mathrm{E}_{\mathrm{p}}, \mathrm{E}_{1 / 2}\right)$ of interaction of $3.2 \times 10^{-3} \mathrm{M} \mathrm{Ca}^{+2}$ ions and different concentrations of $\mathrm{MB}$ at $294.85 \mathrm{~K}$ and scan rate $0.1 \mathrm{~V} / \mathrm{S}$.

\begin{tabular}{|c|c|c|c|c|c|c|c|c|c|}
\hline $\begin{array}{c}\mathrm{mL} \\
\text { of M }\end{array}$ & $\begin{array}{c}{[\mathrm{M}] \times 10^{-3}} \\
\left(\mathrm{mol.L}-\mathrm{L}^{-1}\right.\end{array}$ & Ml of L & $\begin{array}{c}{[\mathrm{L}] \times 10^{-6}} \\
\left(\mathrm{~mol}^{-1}\right)\end{array}$ & Ep,a & Ep,c & $(-) I p, \mathrm{a} \times 10^{-6}$ & Ip,c x10-6 & $\begin{array}{c}\Delta \mathrm{E}_{\mathrm{p}} \\
(\mathrm{v})\end{array}$ & $\begin{array}{c}\mathrm{E}_{1 / 2} \\
(\mathrm{v})\end{array}$ \\
\hline 1 & 3.21 & 0.2 & 1.03 & 0.271 & 0.027 & 7.31 & 7.29 & 0.244 & 0.149 \\
\hline 1 & 3.18 & 0.4 & 2.04 & 0.283 & 0.013 & 9.90 & 0.108 & 0.269 & 0.148 \\
\hline 1 & 3.16 & 0.6 & 3.04 & 0.269 & 0.023 & 7.22 & 7.04 & 0.246 & 0.146 \\
\hline 1 & 3.14 & 0.8 & 4.03 & 0.285 & 0.016 & 9.55 & 8.73 & 0.269 & 0.151 \\
\hline 1 & 3.13 & 1 & 5.00 & 0.30 & 0.008 & 0.109 & 9.30 & 0.292 & 0.154 \\
\hline
\end{tabular}

Table.3(b): The solvation and kinetic parameters $\left(D_{a}, D_{c}, K_{s}, \Gamma_{a}, \Gamma_{c}, Q_{a}, Q_{c}\right)$ of interaction of $3.2 \times 10^{-3} \mathrm{M} \mathrm{Ca}^{+2}$ ions and different concentrations of $M B$ at $294.85 \mathrm{~K}$ and scan rate $0.1 \mathrm{~V} / \mathrm{S}$.

\begin{tabular}{|c|c|c|c|c|c|c|c|c|c|c|}
\hline $\begin{array}{l}\mathrm{mL} \\
\text { of M }\end{array}$ & $\begin{array}{l}{[\mathrm{M}] \times 10^{-3}} \\
\left(\mathrm{~mol} . \mathrm{L}^{-1}\right)\end{array}$ & $\begin{array}{l}\mathrm{Ml} \\
\text { of } \mathrm{L}\end{array}$ & $\begin{array}{l}{[\mathrm{L}] \mathrm{x} 10^{-6}} \\
\left(\mathrm{~mol} . \mathrm{L}^{-1}\right)\end{array}$ & $\begin{array}{l}\text { Da } x 10^{-12} \\
\left(\mathrm{~cm}^{2} \cdot \mathrm{s}^{-1}\right)\end{array}$ & $\begin{array}{l}\text { Dc } \times 10^{-12} \\
\left(\mathrm{~cm}^{2} \cdot \mathrm{s}^{-1}\right)\end{array}$ & $\begin{array}{c}\mathrm{Ks} \mathrm{Cx} 10^{-4} \\
\left(\mathrm{~cm} \cdot \mathrm{s}^{-1}\right)\end{array}$ & $\begin{array}{c}\Gamma \mathrm{c} \times 10^{-9} \\
\left(\mathrm{~mol} / \mathrm{cm}^{2}\right)\end{array}$ & $\begin{array}{c}\text { (+) Qc x } 10^{-6} \\
\text { (C) }\end{array}$ & $\begin{array}{c}\Gamma \mathrm{a} \times 10-9 \\
\left(\mathrm{~mol} / \mathrm{cm}^{2}\right)\end{array}$ & $\begin{array}{c}(-) Q \text { a } \times 10^{-6} \\
\text { (C) }\end{array}$ \\
\hline 1 & 3.21 & 0.2 & 1.03 & 1.45 & 1.44 & 5.16 & 2.446 & 3.71 & 2.452 & 3.72 \\
\hline 1 & 3.18 & 0.4 & 2.04 & 2.69 & 3.22 & 0.136 & 3.634 & 5.51 & 3.320 & 5.03 \\
\hline 1 & 3.16 & 0.6 & 3.04 & 1.45 & 1.38 & 5.32 & 2.361 & 3.58 & 2.422 & 3.67 \\
\hline 1 & 3.14 & 0.8 & 4.03 & 2.57 & 2.14 & 0.104 & 2.928 & 4.44 & 3.205 & 4.86 \\
\hline 1 & 3.13 & 1 & 5.00 & 3.40 & 2.46 & 0.177 & 3.121 & 4.73 & 3.665 & 5.55 \\
\hline
\end{tabular}

Table(4): The values of (Formal potential $\mathrm{E}^{\circ}$, stability constant $\beta_{\mathrm{Mx}}$ and Gibbs free energy $\Delta \mathrm{G}$ ) for $\mathrm{Ca}^{+2}$ ion complexes at $294.85 \mathrm{~K}$ and scan rate 0.1 $\mathrm{V} / \mathrm{S}$.

\begin{tabular}{|c|c|c|c|c|c|c|c|c|c|c|}
\hline $\mathrm{mL}$ of M & $\begin{array}{c}{[\mathrm{M}] \mathrm{x} 10^{-3}} \\
\left(\mathrm{~mol}^{-1}\right)\end{array}$ & $\mathrm{Ml}$ of $\mathrm{L}$ & $\begin{array}{c}{[\mathrm{L}] \mathrm{x} 10^{-6}} \\
\left(\mathrm{~mol}^{-1}\right)\end{array}$ & $\begin{array}{c}(\mathrm{Ep}, \mathrm{a}) \mathrm{M} \\
(\mathrm{v})\end{array}$ & $\begin{array}{c}(\mathrm{Ep}, \mathrm{a}) \mathrm{C} \\
(\mathrm{v})\end{array}$ & $\mathrm{j} \times 10^{-4}$ & $\log [\mathrm{L}]$ & $\log \beta \mathrm{j}$ & $\beta \mathrm{j}$ & $\Delta \mathrm{G}(\mathrm{KJ} / \mathrm{mol})$ \\
\hline 1 & 3.21 & 0.2 & 1.03 & 0.1418 & 0.1491 & 3.20 & -5.989 & 0.251 & 1.781 & -1.415 \\
\hline 1 & 3.18 & 0.4 & 2.04 & 0.1418 & 0.1484 & 6.40 & -5.691 & 0.231 & 1.700 & -1.301 \\
\hline 1 & 3.16 & 0.6 & 3.04 & 0.1418 & 0.1463 & 9.60 & -5.517 & 0.158 & 1.440 & -0.894 \\
\hline 1 & 3.14 & 0.8 & 4.03 & 0.1418 & 0.1508 & 0.128 & -5.395 & 0.316 & 2.072 & -1.786 \\
\hline 1 & 3.13 & 1 & 5.00 & 0.1418 & 0.1545 & 0.160 & -5.301 & 0.441 & 2.762 & -2.491 \\
\hline
\end{tabular}

\subsubsection{Effect of different scan rates}

Effect of different scan rates on the interaction between $\mathrm{Ca}^{+2}$ ions and MB was studied in 0.1, 0.02 and $0.01{\mathrm{~V} . \mathrm{s}^{-1}}^{-1}$ (Fig. 8). The solvation and kinetic parameters (Ep, Ip, $\Delta E_{P}, E_{1 / 2}, D, k_{S}, \Gamma$ and $Q$ ) of different scan rates of $\mathrm{Ca}^{+2}$ ions in the presence of MB were presented in Table 5.(a,b).Randless Sevicek equation was used to apply the relation between cathodic and anodic peak current Ip against the square root of scan rate in $0.1 \mathrm{M} \mathrm{HCl}$ which gives straight lines indicating diffusion process as shown in Fig.9. All scan rate parameters for interaction of MB with calcium acetate are smaller than that of the absence of ligand indicating also the complexation character (Fig.9). It indicates less slope obtained for the complex than the metal supported also the complexation behavior.

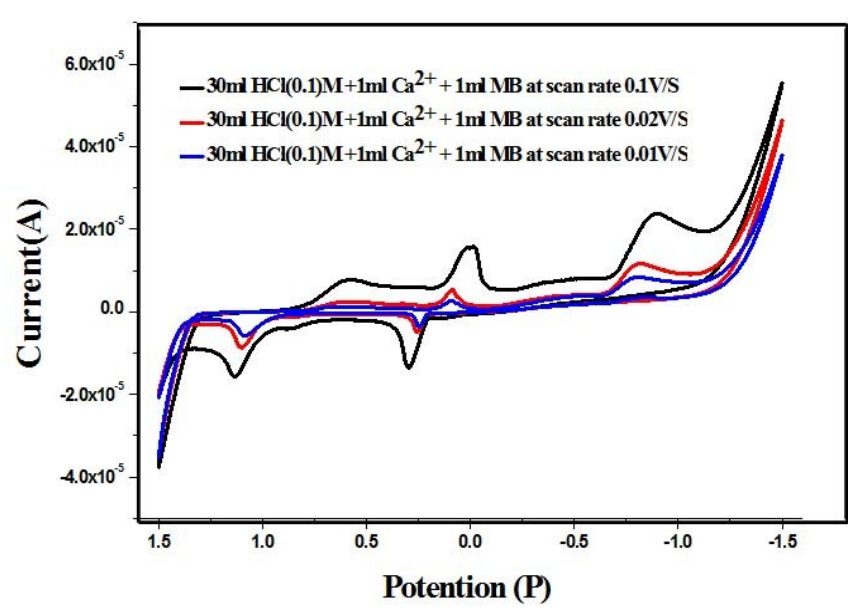

Fig.8. Cyclic voltammogram of different scan rate of $3.13 \times 10^{-03} \mathrm{M} \mathrm{Ca}^{+2}$ ions with $5.00 \times 10^{-06} \mathrm{MB}$ at $294.85 \mathrm{~K}$. 
Table.5(a): The solvation and kinetic parameters (Ep, Ip, $\Delta \mathrm{E}_{\mathrm{p}}, \mathrm{E}_{1 / 2}$ )) of different scan rates of $\mathrm{Ca}^{+2}$ ion complexes at $294.85 \mathrm{~K}$.

\begin{tabular}{|c|c|c|c|c|c|c|c|c|}
\hline $\mathrm{v}$ & $\begin{array}{c}{[\mathrm{M}] \mathrm{x} 10^{-3}} \\
\left(\mathrm{~mol}_{\mathrm{L}}^{-1}\right)\end{array}$ & $\begin{array}{c}{[\mathrm{L}] \mathrm{x} 10^{-6}} \\
\left(\mathrm{~mol}^{-1} \mathrm{~L}^{-1}\right.\end{array}$ & $\mathrm{Ep}, \mathrm{a}$ & $\mathrm{Ep}, \mathrm{c}$ & $\begin{array}{c}(-) \mathrm{Ip}, \mathrm{a} \\
\mathrm{x} 10^{-6}\end{array}$ & $\begin{array}{c}\mathrm{Ip}, \mathrm{c} \\
\mathrm{x} 10^{-6}\end{array}$ & $\begin{array}{c}\Delta \mathrm{E}_{\mathrm{p}} \\
(\mathrm{v})\end{array}$ & $\begin{array}{c}\mathrm{E}_{1 / 2} \\
(\mathrm{v})\end{array}$ \\
\hline 0.1 & 3.13 & 5.00 & 0.300 & 0.009 & 0.109 & 9.30 & 0.292 & 0.154 \\
\hline 0.02 & 3.13 & 5.00 & 0.252 & 0.094 & 3.99 & 3.81 & 0.159 & 0.173 \\
\hline 0.01 & 3.13 & 5.00 & 0.243 & 0.100 & 3.46 & 1.96 & 0.143 & 0.171 \\
\hline
\end{tabular}

Table.5(b): The solvation and kinetic parameters (D, ks, $\Gamma$ and Q) of different scan rates of $\mathrm{Ca}^{+2}$ ion complexes at $294.85 \mathrm{~K}$.

\begin{tabular}{|c|c|c|c|c|c|c|c|c|c|}
\hline$v$ & $\begin{array}{c}{[\mathrm{M}] \times 10^{-3}} \\
\left(\mathrm{~mol}_{\mathrm{L}}^{-1}\right)\end{array}$ & $\begin{array}{c}{[\mathrm{L}] \times 10^{-6}} \\
\left(\mathrm{~mol}_{\mathrm{L}}^{-1}\right)\end{array}$ & $\begin{array}{c}\mathrm{Da} \times 10^{-12} \\
\left(\mathrm{~cm}^{2} . \mathrm{s}^{-1}\right)\end{array}$ & $\begin{array}{c}\mathrm{Dc} \times 10^{-12} \\
\left(\mathrm{~cm}^{2} . \mathrm{s}^{-1}\right)\end{array}$ & $\begin{array}{c}\mathrm{Ks} \mathrm{Cx} 10^{-5} \\
\left(\mathrm{~cm}^{-1}\right)\end{array}$ & $\begin{array}{c}\Gamma \mathrm{c} \times 10^{-9} \\
\left(\mathrm{~mol}^{-9} \mathrm{~cm}^{2}\right)\end{array}$ & $\begin{array}{c}(+) \mathrm{Qc} \times 10^{-6} \\
(\mathrm{C})\end{array}$ & $\begin{array}{c}\Gamma \mathrm{a} \times 10^{-9} \\
\left(\mathrm{~mol}^{-9} \mathrm{~cm}^{2}\right)\end{array}$ & $\begin{array}{c}(-) \mathrm{Qax} 10^{-5} \\
(\mathrm{C})\end{array}$ \\
\hline 0.1 & 3.13 & 5.00 & 3.4 & 2.463 & 0.0017 & 3.121 & 4.73 & 3.665 & 0.55 \\
\hline 0.02 & 3.13 & 5.00 & 2.27 & 2.065 & 7.98 & 6.389 & 9.68 & 6.696 & 1.01 \\
\hline 0.01 & 3.13 & 5.00 & 3.4 & 1.092 & 3.28 & 6.571 & 9.95 & 0.115 & 1.76 \\
\hline
\end{tabular}

Table 6: The solvation and kinetic parameters (Ep, Ip, $\Delta \mathrm{E}_{\mathrm{P}}, \mathrm{E}_{1 / 2}, \mathrm{D}, \mathrm{k}_{\mathrm{S}}, \Gamma$ and Q) of $0.1 \mathrm{M} \mathrm{HCl}, 3.13 \times 10^{-03} \mathrm{M} \mathrm{Ca}^{+2}$ ions and $5.00 \times 10^{-06} \mathrm{MB}$ at $294.85 \mathrm{~K}$ and scan rate $0.1 \mathrm{~V} / \mathrm{S}$.

\begin{tabular}{|c|c|c|c|c|c|c|c|c|c|}
\hline $\mathrm{mL}$ of M & $\begin{array}{c}{[\mathrm{M}]} \\
\left(\mathrm{mol}_{\mathrm{L}}^{-1}\right)\end{array}$ & $\mathrm{mL}$ of L & $\begin{array}{c}{[\mathrm{L}]} \\
\left(\mathrm{mol}^{-1}\right)\end{array}$ & $\mathrm{Ep}, \mathrm{a}$ & $\mathrm{Ep}, \mathrm{c}$ & $\Delta \mathrm{Ep}$ & $(-) \mathrm{Ip}, \mathrm{a} \times 10^{-5}$ & Ip,c x10-6 & $\mathrm{E}^{\circ}$ \\
\hline 0 & 0 & 0 & 0 & 1.16 & 1.162 & 0.767 & 0.431 & 6.30 & 0.965 \\
\hline 1 & $3.23 \times 10^{-3}$ & 0 & 0 & 1.15 & 1.146 & 0.596 & 1.29 & 6.27 & 0.871 \\
\hline 1 & $3.13 \times 10^{-3}$ & 1 & $5.00 \times 10^{-6}$ & 1.13 & 1.128 & 0.584 & 1.13 & 6.51 & 0.856 \\
\hline
\end{tabular}

\begin{tabular}{|c|c|c|c|c|c|c|c|}
\hline $\begin{array}{c}\mathrm{Da} \\
\left(\mathrm{cm}^{2} . \mathrm{s}^{-1}\right)\end{array}$ & $\begin{array}{c}\mathrm{Dc} \\
\left(\mathrm{cm}^{2} \cdot \mathrm{s}^{-1}\right)\end{array}$ & $\mathrm{Epc} / 2$ & $\begin{array}{c}\mathrm{Ks} \mathrm{C} \\
\left(\mathrm{cm}^{-1}\right)\end{array}$ & $\Gamma \mathrm{c} \times 10^{-9}$ & $\begin{array}{c}(+) \mathrm{Qc} \times 10^{-6} \\
(\mathrm{C})\end{array}$ & $\Gamma \mathrm{a} \times 10^{-9}$ & $\begin{array}{c}(-) \mathrm{Q} \mathrm{a} \times 10^{-6} \\
(\mathrm{C})\end{array}$ \\
\hline 0 & 0 & 0.826 & 0.000 & 2.111 & 3.20 & 1.445 & 2.19 \\
\hline $4.46 \times 10^{-12}$ & $1.05 \times 10^{-12}$ & 0.704 & 0.149 & 2.104 & 3.19 & 4.337 & 6.57 \\
\hline $3.62 \times 10^{-12}$ & $1.21 \times 10^{-12}$ & 0.700 & 0.134 & 2.183 & 3.31 & 3.784 & 5.73 \\
\hline
\end{tabular}

\subsection{Effect of $\mathrm{HCl}(0.1) \mathrm{M}$ as a supporting electrolyte.}

From Fig.10, it was observed that $\mathrm{HCl}(0.1) \mathrm{M}$ as a supporting electrolyte show a cathodic peak which disappear by adding $\mathrm{Ca}^{+2}$ ions and $\mathrm{MB}$ due to complexation.

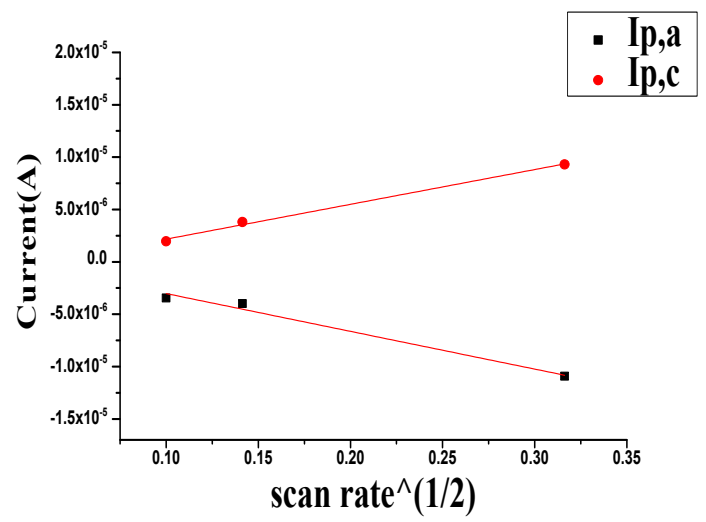

Fig.9. The relation between peak current Ip (ip,a - ip,c)

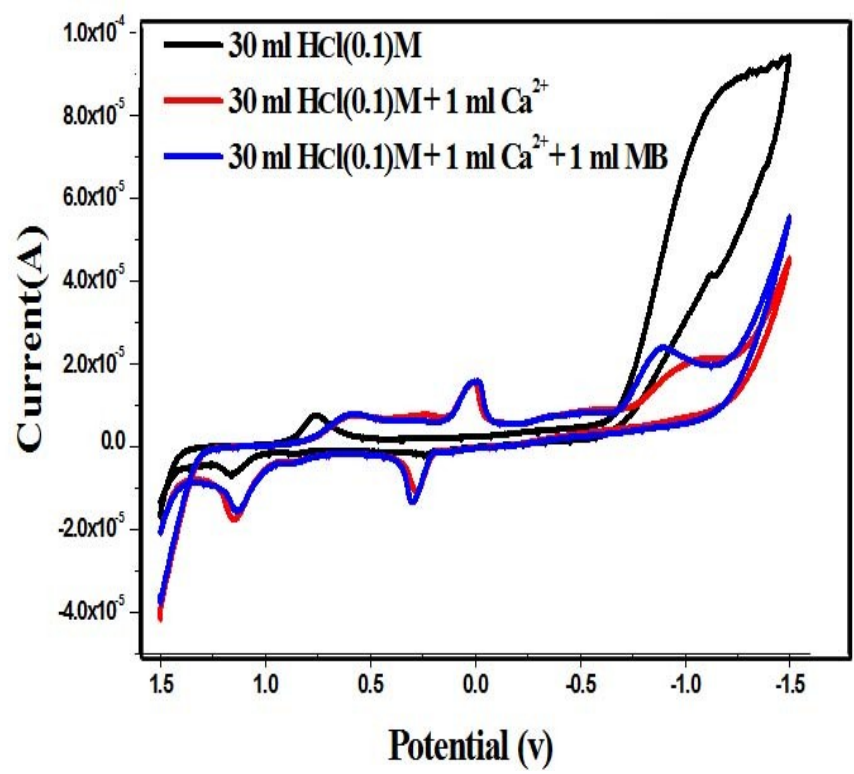

Fig.10. Cyclic voltammogram of $0.1 \mathrm{M} \mathrm{HCl}, 3.13 \times 10^{-03} \mathrm{M} \mathrm{Ca}^{+2}$ ions and $5.00 \times 10^{-06} \mathrm{MB}$ at $294.85 \mathrm{~K}$ and scan rate $0.1 \mathrm{~V} / \mathrm{S}$.

against different scan rates of $\mathrm{Ca}^{+2}$ ions with $\mathrm{MB}$ at $294.85 \mathrm{~K}$. 


\section{Conclusion}

The cyclic voltammetry of the supporting electrolyte $(0.1 \mathrm{M} \mathrm{HCl})$ was obtained by using Gold electrode (GE). One reduction wave was obtained at $\sim-1$ $\mathrm{V}$ corresponding to the reduction of gold chloride to gold metal. By adding different concentrations from calcium acetate appearance of two new waves happened, one reduction peak at $\sim 0.0 \mathrm{~V}$ and one oxidation peak at $\sim 0.25$ $\mathrm{V}$ corresponding to the reduction and oxidation of calcium ions. All the kinetic parameters [anodic diffusion coefficient $D_{a}$, cathodic diffusion coefficient $D_{C}$,electron rate constant $K_{s}$, anodic quantity of electricity $Q_{a}$, cathodic quantity of electricity $Q_{c}$, anodic and cathodic surface coverage, $\Gamma_{\mathrm{a}}, \Gamma_{\mathrm{c}}$ ] for calcium acetate concentrations are increased by increasing in the concentrations of calcium acetate favoring diffusion controlled reactions. The calcium peaks were increased in intensity by adding methylene blue (MB) to calcium ions, the potential of reduction peak was shifted to more negative and the potential of oxidation peak was shifted to more positive values. All the results, indicate that the solvation and kinetic parameters $\left[K_{s}, Q_{a}, Q_{c}, \Gamma_{a}, \Gamma_{c}\right]$ of the complexation reaction between $\mathrm{MB}$ ligand and $\mathrm{Ca}^{+2}$ ions are smaller than that for $\mathrm{Ca}^{+2}$ ion in $\mathrm{HCl}$ solution as supporting electrolyte The thermodynamic parameters [stability constant, $\beta \mathbf{j}$ and Gibbs free energies of complexation, $\Delta \mathrm{G}$ ] for the interaction of $\mathrm{MB}$ with $\mathrm{Ca}^{+2}$ ions are increased by increasing the concentration of MB in solutions indicating more complexation.

\section{References}

[1] M.L. Mai, M. Emmett, M.S. Sheikh, C.A. Santa Ana, L. Schiller and J.S. Fordtran. Kidney International, 1989, 36, 690-695.

[2] P.T. Scaria, R. Gangadhar and R. Pisharody. Indian journal of pharmacology, 2009, 41, 187-191.

[3] M.S. Sheikh, J.A. Maguire, M. Emmett, C.A. Santa Ana, M.J. Nicar, L.R. Schiller and J.S. Fordtran. The Journal of clinical investigation, 1989, 83, 66-73.

[4] G.R. Davis, C.A. Santa Ana, S.G. Morawski and J.S. Fordtran. Gastroenterology, 1980, 78, 991-995.

[5] E.A. Gomaa, A. Negm and M.A.K. Tahoon. European Journal of Chemistry, 2016, 7, 341-346.

[6] E.A. Gomaa, A. Negm and R. Abou Qurn. Iranian Journal of Chemical Engineering(IJChE), 2017, 14, 90-99.

[7] E.A. Gomaa, A. Negm and R.M. Abu-Qarn. Measurement, 2018, 125, 645-650.

[8] E.A. Gomaa, A.G. Al-Harazie and M.N. Abdel-Hady. Chemical Methodologies, 2018, 2, 186-193.
[9] E.S.E. El-Sherifi, E.A. Gomaa, A.A.E. Negm, A.M. Yousif and A.S. Abou-Elyazed. Assiut University Journal of Chemistry, 2018, 47, 38-50.

[10] E.A. Gomaa, M.H. Mahmoud, M.G. Mousa and E.M. El-Dahshan. Chemical Methodologies, 2019, 3, 111.

[11] E.A. Gomaa, R.R. Zaky, A.A.E. Negm and R.T. Rashad. Assiut University Journal of Chemistry (AUJC), 2018, 47, 21-28.

[12] E.A. Gomaa, M.A. Morsi, A.E. Negm and Y.A. Sharif. Assiut University Journal of Chemistry (AUJC), 2018, 47, 29-37.

[13] E.A. Gomaa, M. Diab, A. Elsonbati, H.M. Abulenader and A. Helmy. Asian Journal of Nanosciences and Materials, 2018, 1, 225-233.

[14] M.A. Morsi, E.A. Gomaa and A.S. Nageeb. Asian Journal of Nanosciences and Materials, 2018, 1, 282-293.

[15] H.M. Killa, E.E. Mercer and R.H. Philp. Analytical Chemistry, 1984, 56, 2401-2405.

[16] H. Killa, E. Mabrouk, M. Moustafa and R. Issa. Croatica Chemica Acta, 1992, 64, 585-592.

[17] E. Gomaa, M. Mousa and A. El-Khouly. Thermochimica acta, 1985, 89, 133-139.

[18] E.A. Gomaa. Thermochimica Acta, 1988, 128, 99-104.

[19] E.A. Gomaa. Bull. Soc. Chim Fr., 1989, 5, 371.

[20] E.A. Gomaa. Thermochimica acta, 1989, 156, 91-99. 